\title{
A casa de João*
}

\author{
Mirsa Elisabeth Dellosi
}

\section{O que é um grande presente?}

Recebi um telefonema, no dia 20 de dezembro de 2005, no CAPS Luiz da Rocha Cerqueira, em São Paulo. Do outro lado da linha estava o "Seu” João. Ele pedira à Gabriela, assistente técnica do CRCB - Centro de Reabilitação de Casa Branca (hospital psiquiátrico próprio do Estado) para ligar para mim. Quis me dar a notícia pessoalmente: construiu sua casa própria e já está morando nela, na cidade de Casa Branca.

Um misto de alegria e orgulho tomou conta de nossas palavras. Não sei quem estava mais feliz - ele, com certeza, mas eu vibrei, pois há muito tempo o sentimento de solidariedade pela conquista, pela vitória de um outro, não me tocava tão fortemente.

Dei-lhe os parabéns entusiasmada, emocionada! Convidou-me para conhecer sua casa, respondi então que iria visitá-lo.

Pedi o endereço para mandar um cartão de Natal.

Não é a primeira vez que João me procura para dizer de seus passos em direção à sua cidadania. Para mim, ele tornou-se um dos símbolos da resistência à segregação, aos preconceitos impostos por longos anos de internação em hospital psiquiátrico.

* Publicado originalmente na Revista Latinoamericana de Psicopatologia Fundamental, v. IX, n. 1, p. 1-4, mar/2006. 
Seria necessário pedir-lhe permissão para escrever este texto? Estaria ele de acordo com a publicação? Sua história é inevitavelmente pública!

Percebi uma alegria tímida em sua voz trêmula ao telefone: “Já estou morando lá!”. Construiu a casa com as próprias mãos! Comprou o terreno e ergueu sua moradia... O dinheiro foi conseguido através do benefício da LOAS e do Programa de Volta para Casa - direitos adquiridos, graças ao empenho da equipe do CRCB.

Numa velocidade impensável seu telefonema me trouxe a lembrança de cenas delicadas e emocionantes: “Seu” João participando da Comissão Estadual de Reforma Psiquiátrica, falando na Conferência Regional de Saúde Mental em São João da Boa Vista, participando da Conferência Estadual de Saúde Mental, no Anhembi, em São Paulo, votando na Conferência Nacional de Saúde Mental, em Brasília. Primeira viagem de avião, primeira visita à Capital da República... Isto lhe valeu admiração de familiares e o convite para que fosse até eles e contasse essa experiência. "Seu” João esteve também em Paracambi, no Encontro Brasileiro sobre Residências Terapêuticas. Nessa cidade do Estado do Rio de Janeiro, ele e o seu colega Ariovaldo (o "Magrão") foram sacar pela primeira vez o dinheiro do Programa de Volta para Casa, pois tinham deixado Casa Branca e não tiveram tempo de usar o cartão da Caixa Econômica Federal. Estavam contentes, pois foram os primeiros beneficiários a sacar, fora do município onde residem. Isto trouxe para os dois um lugar na mesa de encerramento do Encontro e, conseqüentemente, muitos aplausos!

Um sentimento incontrolável de admiração trouxe-me a lembrança de um quartinho abarrotado de móveis e eletrodomésticos, cuidadosamente embalados e estocados numa das casas do CRCB, que "Seu” João foi comprando e guardando aos poucos, durante meses, senão anos, para o dia que deixasse definitivamente o hospital.

Era julho de 1999. Iniciávamos a intervenção e a reconstrução coletiva, junto à equipe, do Projeto Terapêutico Institucional do Centro de Reabilitação de Casa Branca. “Seu” João sempre participava das reuniões dos usuários realizadas no cinema do CRCB onde fiquei sabendo que ele dormia numa cama de uma das casas do Centro. Esclareço que até então ele participava da rotina indiferenciada do hospital, sem nenhum projeto terapêutico individual, sendo que a diferença era o lugar onde dormia, ou seja, numa cama fora dos pavilhões.

Quando fui conhecer as pessoas que dormiam nessa casa, entre elas "Seu" João, fiquei surpresa com o quarto lotado com seus pertences, embalados em plásticos. Questionei à equipe:

— Se este homem tem condições de receber alta imediatamente, por que não apoiá-lo?

Alguém respondeu: 
— Ele tem medo de sair do hospital.

Ouvi esta fala com profundo pesar e perguntei:

— Quem aqui cuida do medo? Não é uma equipe “psi”? ou seria necessário um engenheiro?, ironizei.

Todas as vezes que pude, durante um ano e meio de intervenção, procurei animar "Seu” João a obter sua alta e ir morar na cidade, até que um dia descobri qual era o medo. Conversando com ele na sua simplicidade, perguntou-me:

- Se eu for morar na cidade, posso vir aqui continuar a cuidar da horta, continuar participando da oficina de cabides e do ateliê e rever meus amigos?

— Claro "Seu” João, por que não?

— É que me disseram que se eu for embora não posso mais vir aqui.

Indignada respondi:

- Isso é um absurdo. Quem foi que lhe disse isso?

Ele não declarou, apenas respondeu:

- É o que me disseram.

Este homem viveu 31 anos internado e fez amigos nos pavilhões pelos quais passou. O medo era perder vínculos afetivos e não - como primariamente imaginava a equipe - o de deixar o hospital e morar na cidade. Este desejo estava materializado nas compras que fizera, silenciosamente, ao longo de um tempo.

Assegurei-lhe que se fosse morar na cidade poderia continuar a cuidar da horta, fazer cabides etc. Ninguém poderia impedi-lo.

"Seu” João sorriu...

— É verdade?!

Soube mais tarde, já no final da intervenção, que no dia 20 de setembro de 2000, “Seu” João solicitou a própria alta e a equipe, superando talvez o próprio medo, vê a mudança sair do CRCB para uma casa alugada por João e mais três companheiros desinternados os quais, rateando o aluguel, inauguram a primeira residência terapêutica no centro do município de Casa Branca.

Nessa cidade, as imobiliárias aboliram o preconceito porque estes cidadãos revelaram-se ótimos inquilinos. Muitos outros “moradores” do CRCB continuaram esta caminhada. Hoje, são 33 homens que habitam oito casas por eles alugadas. No CRCB, as residências terapêuticas são 38 casas, onde moram 136 pessoas, entre homens e mulheres que receberam a alta hospitalar.

João, porém, ainda não estava satisfeito... Um dia, ele me contou que comprara um terreno. Meu coração ficou enternecido. Neste telefonema comunicou-me que sua casa própria está pronta e já está morando nela! A primeira compra de material de construção foi feita em maio deste ano, para a qual recebeu apoio e orientação da associação de usuários, familiares, funcionários e amigos da saúde mental, chamada Associação Barões de Cocais (o Barão de Cocais doou as terras onde se construiu o CRCB, em 1932, internando hansenianos até 1970, 
quando se transformou em hospital psiquiátrico). Essa associação foi criada em 1999, seu nome votado em assembléia dos usuários e desde então presidida por um funcionário. Para minha surpresa, graças à equipe do CRCB, desde 2004 seu presidente é o "Senhor” João, hoje o maior incentivador para que muitos outros aluguem e construam suas casas na cidade.

Não sei quantas pessoas podem testemunhar uma história como esta... Tenho que agradecer ao João pelo imenso privilégio de conhecê-lo.

A Casa de João simboliza e concretiza o melhor da Reforma Psiquiátrica no Estado de São Paulo. É a alta da residência terapêutica.

O que é um grande presente?

Para mim foi esse telefonema do João. Ele sabe disso. Imaginei seu semblante sereno compartilhando desta alegria, embora sua voz fosse trêmula...

A Casa de João é mais bonita do que a de José (Saramago), pois não há palavras que possam escrever esta bela história de liberdade!

Em 2006 vou tomar café na Casa de João.

São Paulo, 24 de dezembro de 2005. 